\title{
The students' attitudes and entrepreneurial intention: Evidence from Vietnam universities
}

\author{
Nguyen Thi Minh Phuong ${ }^{a^{*}}$, Thai Hoang Quoc ${ }^{a}$, Le Van Cupa and Le Thi Kim Lien ${ }^{a}$
}

${ }^{a}$ Department of Tourism, Hong Bang International University, Vietnam

\begin{tabular}{l}
\hline C H R O N I C L E \\
\hline Article history: \\
Received: September 10, 2020 \\
Received in revised format: \\
October 102020 \\
Accepted: October 22, 2020 \\
Available online: \\
October 22, 2020 \\
\hline Keywords: \\
Startups \\
Entrepreneurial Intention \\
University students \\
Personal traits \\
Social norms \\
\hline
\end{tabular}
A B S T R A C T

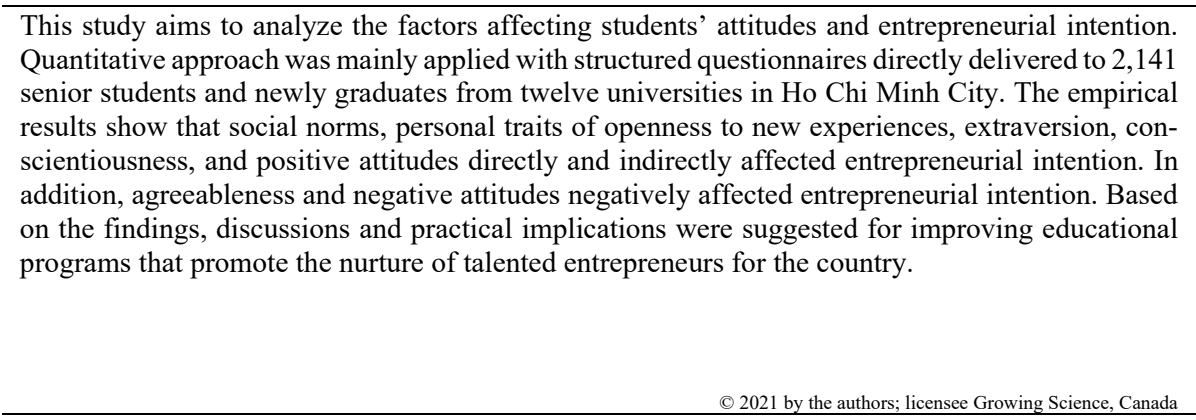

\section{Introduction}

Vietnam is a dynamic country with a young labour force, especially in the context that Vietnam is needed many strong young businesses in all fields to get competitive advantage and keep market share before foreign companies.According to the General Statistics Office, in 2017, there were 517,900 registered enterprises. Although the number of enterprises increases, there are only 10,100 large enterprises accounted for $1.9 \%$. SMEs accounted for $98.1 \%$, and medium enterprises had nearly 8.5 thousand enterprises, an increase of $23.6 \%$ compared to 2012- 2017; small business is 114.1 thousand and micro enterprise 385.3 thousand, the number of SMEs increased by $8.8 \%$, higher than the average growth rate of large enterprises of $5.4 \%$ (tapchitaichinh.vn). It can be said that startups have contributed more than $40 \%$ of gross domestic product (GDP) to the remarkable growth of the Vietnamese economy. Although the important role of the entrepreneurship has proven to be important to every economy through numerous statistical reports, and there was a lot of studies on entrepreneurship around the world, the research on this matter in the context Vietnam is still very limited and has not found any effective solution for policymakers and educators in training and developing a contingent of talented entrepreneurs for the country in the future. This purpose of this study is to explore the factors affecting students' attitudes toward self-employment intention.

\section{Literature Review}

\subsection{Entrepreneurship}

Entrepreneurship is a nascent developing area which is receiving the concentration from the scholars due to the increasing impacts on the global business climate. Based on the assumption of (Gregoire et al., 2006), the theory, which was proposed by Schumpeter in 1934, can be analyzed like the foundation of entrepreneurship research. Schumpeter (1934), suggested a distinct perspective of entrepreneurship that went beyond the classical viewpoint by analyzing the entrepreneurs like

* Corresponding author.

E-mail address: phuongntm2@hiu.vn (N. T. M. Phuong) 
innovators, generating new movements and marketplace to disrupt the "status quo". The entrepreneurship can be analyzed through three core domains of level of analysis such as the individual, firms, and socio-economic systems (Korber \& McNaughton, 2018). Carland et al. (1984) recommended that entrepreneurship is a peculiar aspect which distinguishes the entrepreneurs from administrators or staffs. Moreover, entrepreneurs are illustrated as the person who explores take the initiate to pursue the activities in order to establish a new business. Entrepreneurship is a distinctive attribute of entrepreneurs who regularly look for and determine the chances and enhance the firm's development. (Brockhaus, 1980).

\subsection{Entrepreneurial intention}

It is a tough field to research the intention to start a business of university students. In general, the term "entrepreneurial intention" is usually clarified as the choice to establish a new firm (Krueger et al., 2000; Fitzsimmons \& Douglas, 2011; De Clercq et al., 2012). For the student, it is related to the decisions that is not required to make at the present time, but potentially in the forthcoming periods, usually several years and/or at the time they were graduated, left their university. In addition, several scholars such as Churchill and Bygrave (1989); Obschonka et al. (2010); and Remeikiene et al. (2013) have clarified the term "entrepreneurial intention" like a judicious process in the way of thinking and behave, turning into the motivation and plan to launch a new business or generate new scope in the current firms. Besides that, Krueger (2007) believed that the decision-making process leads to individuals work, create, and establish organizations willfully, which is a consequence of the choice to become an entrepreneur. By conducting empirical research, Krueger et al. (2000) and Obschonka et al. (2010) confirmed the notion of intention is the best indicator of entrepreneurial attitudes. Based on the suggestion of Ajzen (1988, 1991), Krueger et al. (2017) proved that entrepreneurial intention can be constructed through a meaning of bridge that link the organization creations and exogenous impacts.

The entrepreneurial even model: Shapero and Sokol (1982) created the foundation of the intention-based model. They proposed the model on antecedents of entrepreneurial intention and claimed that the discretion of an individual including desirability, feasibility, and propensity are the essential elements that manage and motivate that person to shape the intention to establish a new firm. The model contains one dependent variable, which is determined as the "entrepreneurial intention", is related to the anticipated entrepreneurial attitudes of the senior students of MAUTECH; and three independent variables which are related to the behaviors of an individual on entrepreneurship, including perceived desirability; perceived feasibility and perceived propensity.

The theory of planned behavior entrepreneurial model: Krueger and Carsrud (1993) expanded the work of Ajzen (1991) to generate the theory of planned behavior entrepreneurial model. The theory of planned behavior interpreted that a person's point of views, recognized behavioral authority, and recognized social norms lead to the behavioral intention (Ajzen, 1988).

The Douglas and Shepherd's (2002) entrepreneurial intention model: In 2002, Douglas and Shepherd created a new framework to examine the impacts of an individual's attitude toward entrepreneurship on the entrepreneurial intention. They investigated the empirical research within the university context by conducting the analysis with the sample of ninety-four alumni of an Australian university who had graduated with their Bachelors of Business degree between two and ten years formerly. The antecedents of the university students' entrepreneurial intention consist of attitudes to work effort, attitudes to risk, and attitudes to independence.

The purpose of this study is to investigate the impacts of the antecedents of entrepreneurial intention in the university context. This study follows and enlarges the Shapero and Sokol (1982) and Douglas and Shepherd (2002) model by examining the direct impacts of personal traits (which is determined based on the Big five indicators) and social norms on the entrepreneurial intention, as well as the attitudes towards entrepreneurship. In addition, the study analyzes role of the attitudes towards entrepreneurship in the framework as the mediating variable.Moreover, due to the fact this study add the personal traits as the antecedent of the entrepreneurial intention. It also consults the model of Nguyen and Phan (2014). The model demonstrated the impacts of personal traits and motives for the youthful people in Vietnam, especially the senior students.

\subsection{Attitude towards Entrepreneurship}

\subsubsection{Positive Attitudes}

The previous research articles have determined the attitude towards entrepreneurship. Especially, the framework of Shapero and Sokol (1982) recommended perceived desirability; perceived feasibility and perceived propensity have direct influences on the intention of start-up. Thus, the positive perceptions of an individual toward entrepreneurship are the essential components that can actually affect and change that individual's thoughts and actions about start-up. Perceived desirability correlated to the perspective of the results of the particular actions, including "income, autonomy, ownership, risk taking and work effort" (Douglas \& Shepherd, 2008). Eisenhauer (1995) created a framework that demonstrated the choice to become entrepreneurs is the result of the needs to gain, which can be gathered from the "working conditions" or the organizational climate of the field works in comparing to the independent business. Douglas and Shepherd (2000) conducted an empirical study which investigated the impacts of entrepreneurial point of views on entrepreneurship and showed the connection between a person's earnings potential and opinions on entrepreneurship. In specific, in that study, they analyzed the notions of an individual on work conditions of an organization through several factors like necessary effort, hazard disclosure, and decisionmaking self-government. Thus, an individual's decision to become an entrepreneur to launch a new business or an employee to work within the existing firm is influenced through the entrepreneurial point of view. Moreover, Douglas \& Shepherd 
(2000) also recommended that the "individuals' income, work effort, risk taking, independence, and other working conditions" can improve and satisfy an individual's needs and expectation. These results from Douglas \& Shepherd (2000) demonstrated that the existence of a mixture of "income, risk, work effort required, and independence" provides benefits than the advantages of self- employment alternatives, an individual will have the tendency to start his/her own firm. Douglas \& Shepherd (2002) proved that an individual's self-efficacy is a foundation of the intention to become an entrepreneur instead of being employed. Thus, the positive attitudes toward entrepreneurship; including attitudes toward working conditions, financial benefits, quality of life, and other conditions are analyzed as the antecedents of entrepreneurial intention within this study's framework.

\subsubsection{Negative Attitudes}

An individual who has higher indulgence for hazards tends to receive fewer disutility from risk endurance. The employment alternative is certain and sustainable option for the person who resists to risks due to the fact that a staff continuously earn a certain wage. On the other hand, self-employment alternative, which represents the choice to become entrepreneurs and has the characteristic of risk acceptance (Knight, 1921; Duchesneau \& Gartner, 1990). Thus, according to Shapero and Sokol (1982), the perceived desirability includes "income, autonomy, ownership, risk taking and work effort". Knight (1921) and Duchesneau and Gartner (1990) claimed that the more a person takes risk, the higher percentage the person will become an entrepreneur. Therefore, the hazard patience or the hazard resistance creates the positive or negative attitudes towards entrepreneurship, respectively. After that, both of them may affect an individual's intention to create a new business. In other words, the attitude to risk may directly influence the career decision (Douglas \& Shepherd, 2002), and a less hazard resistance behavior tends to motive an individual to select a start-up option (Rees \& Shah, 1986).

\subsection{Personal Traits}

Various scholars have concentrated on the term "personal traits" (Robbins \& Judge 2007) and used it like an element to forecast the entrepreneurial intention (Ciavarella et al., 2004). Goldberg (1981) proposed that most of the human beings' distinction comes from the root of personality or characteristic, which can be classified to five components. He concluded that the personal traits which is the combination of agreeableness, openness to experience, extraversion and conscientiousness positively influence the entrepreneurship intention while neuroticism have the contrastive impacts. This is an idea that five elements can integrate to make an appropriate model for displaying higher-order personality distinctions between human beings (McCrae \& Costa, 1999; Wiggins \& Trapnell, 1997). Empirically, the Big Five Indicators suggested that an individual can be interpreted based on these five components (Ććkalo \& Rajković, 2018). The first components of Big Five indicators is associated with agreeableness which is determined whether a person is bountiful, melodious, benignant, etc. (Graziano \& Eisenberg, 1997), The second element is openness to experience which is clarified whether an individual is inventive, productive, thoughtful, etc. (McCrae \& Costa, 1997). The third dimension is extraversion which is the quality to which an individual is vivacious, affirmative, loquacious, and so on (Watson \& Clark, 1997; Lucas et al., 2000; and Ashton et al., 2002). The next dimension is conscientiousness which is illustrated whether a person is obedient, organized, trustworthy, etc. (Hogan \& Ones, 1997). Finally, the neuroticism which is the quality to which a person is solicitous, moody, contentious, and so on (Widiger \& Costa, 1994). Moreover, Ćoćkalo and Rajković (2018) supported that notions by suggested that the characteristics of a person have a significant on entrepreneurial intention and entrepreneurial behaviors. In specific, several scholars paid the attention to the Big Five indicators. Big Five personality traits were applied to forecast the thoughts of becoming an entrepreneur (extraversion, agreeableness) and launch a new firm (openness) (Antoncic et al., 2005). In addition, Zhao et al. (2010) showed that the four major Big Five elements direct influences the entrepreneurial intentions (all but except the agreeableness). In a research within the social entrepreneurship area, Nga and Shamuganathan (2010) and Caballero et al. (2013) also proposed that the agreeableness, openness and conscientiousness can be applied to predict the social entrepreneurial intention. Moreover, Zhao \& Seibert (2006) also placed an emphasis on the openness and agreeableness elements associated with the willingness to become an entrepreneur (Caballero et al., 2013).

\subsection{Social Norms}

According to Ajzen (1991), in The Theory of Planned Behavior (TPB), the behavioral intentions are determined by three main "attitudinal antecedents includes attitudes towards performing the behaviors, social norms, and perceived behavioral control". After that, Krueger \& Carsrud (1993) expanded the theory of planned behavior and recommended that establishing a new firm is a willful procedure which is impacted through three variables, including point of view about the enterprise formation, the social norms for commitment in business establishment, and recognized manipulation for entrepreneurial attitudes.

Combining to the personal traits which is the endogenous dimensions, this study focuses on the second element of the theory of planned behavior in order to examine the exogenous elements that influence the mindset of an individual, turning to the choice of become an entrepreneur. Ajzen \& Fishbein (2005) stated that both kinds of the social norms, which consists of injunctive social norms and descriptive norms, should be studied to enlarge the knowledge of the influences of external environment on an individual's intentionality. Ajzen (1988) interpreted the term "social norm" like the individual's discretion of communal tension to operate or not to operate the attitudes under inspection. In other words, it displays a person's perspective of values, mindset, assumptions, and observances which are occupied by the others who affect significantly to him/her or whom he/she really appreciate. For instance, due to the beliefs of the majority in the society, parents in Vietnam have the tendency to place the pressure and force their children to elect "doctor" or "engineer" as the future career because those 
occupations are acknowledged as the reputable and far-famed business. According to Elfving et al. (2009), the social norms can be distinct across nations and have higher impacts on the society in some nations than other countries. The essential social norms in the entrepreneurial intention research field are displayed in various forms like "role model" or instructor in Krueger's (2000) model, networking in Shapero \& Sokol's (1982) framework, influences of social media in World Economic Forum's (2013) study, and social status (motive element) in Nguyen \& Phan's (2014) research. This study consults the previous recommendation and analyzes the social norms as the independent variable in several forms from the research of Krueger (2000), Shapero \& Sokol (1982), and Nguyen \& Phan (2014).

\section{Hypotheses}

Hence, depend on the literature review by these researchers, we developed the hypotheses to be tested as below:

$\mathrm{H}_{1}$ : There are factors that positively affect and predict positive attitudes.

$\mathrm{H}_{2}$ : There are factors that positively affect and predict negative attitudes.

$\mathrm{H}_{3}$ : There are factors that affect entrepreneurial intention.

$\mathrm{H}_{4}$ : The components of entrepreneurial intention have direct and indirect effects on attitudes.

\section{Methods}

\subsection{Sample}

This research collected a sample of to 2,141 senior students and newly graduates from twelve universities in Ho Chi Minh City. Hair et al. (1995), recommended variable ratio of 5:1 (Hair et al, 1995). This study has a total of 30 observed variables, so the necessary sample size is minimum: $5 \times 30=150$ surveys. As reported by Kerlinger (1986) and Hinkle et al. (1988) were linked with sample size, which the larger sample is the smaller error, data selected in different ways through students' email, face to face, online surveys. In addition, we have a big help from twelve universities' staff to collect data by using convenience sampling from November 2019 to August 2020.

\subsection{Measure scales}

The questionnaire was designed based on theory, concepts, literature review from previous studies. The dependent variable “entrepreneurial intention" was adapted as measure scales by Turker Duygu (2009), Fitzsimmon et al. (2011), and Nguyen \& Phan (2014). The mediating variables "Positive and negative attitudes" were used measure scales by Douglas \& Shepherd (2002) and Shapero \& Sokol (1982). The independent variables "social norms" was adapted measure scales by Krueger Jr et al. (2000), and Nguyen \& Phan (2014). Finally, the independent variables of "personal traits" includes agreeableness, openness to new experiences, extraversion and conscientiousness and the measure scales were adapted from Kovaleva et al. (2013). There are some demographic characteristics such as gender, age group, marital status, university, field of study, and educational grade of respondents were used as control variables and also evaluated.

\section{Results}

\subsection{Descriptive information}

This research conducted a quantitative research method, the SPSS software (20.0 version) was used to analyze 2,141 responses in this study at confidence level of $95 \%(\mathrm{P}<.05)$. The study used some statistical techniques to analyze the data such as, factor analysis, and descriptive statistics of means and standard deviations. Finally, the multiple regression was used to test the hypotheses to find out the relationship between students' entrepreneurial intention, positive and negative attitudes and social norms, personal traits. The dependent variables were .811 by measure of sampling adequacy of The Kaiser-MeyerOlkin's (KMO), and the independent variables were .790 by measure of sampling adequacy of The Kaiser-Meyer-Olkin's (KMO). The results indicated that the data was appropriate for "principal components analysis". In addition, the "Bartlett's test of Sphericity" value was significant with sig $=.000(p<.001)$ (Pallant, 2005), then our findings pointed out all items of all variables were considered applicable to the analysis. Since the "Kaiser-Guttmann's retention criterion of Eigenvalues" must be above 1.0, the first three components of the dependent variables have eigenvalues greater than 1.0 and contributed $50.3 \%$ to the total variance. Furthermore, the first six components of independent variables have eigenvalues greater than 1.0 and contributed $58.1 \%$ to the total variance. Thus, all these variables were considered satisfactory (Hair, Anderson and Tatham, 1987). The core reliability of the observed variables inside every hypothesis was analyzed by primary component factor analyses. After that Cronbach's alpha was computed as a reliability test for the hypothesis, multiple regression was employed to estimate the relationship between independent variables, mediating variables, dependent variables, and path analysis. The results presented in Table 1 showed that Cronbach's alpha for all constructs have reliability range from .604 to .785, which indicated that the existing data are appropriated to principal components analysis that indicated good subscale reliability (Table 1). Pallant (2007) stated that the factors are significant when the value are at least .60 or above. 
Table 1

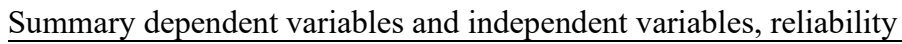

\begin{tabular}{|c|c|c|}
\hline Construct & Items & $\begin{array}{c}\text { Cronbach's alpha } \\
(\mathrm{N}=2,141)\end{array}$ \\
\hline ENIN: Entrepreneurial Intention & 4 & .711 \\
\hline POSAT: Positive Attitudes & 6 & .765 \\
\hline NEGAT: Negative Attitudes & 4 & .652 \\
\hline \multicolumn{3}{|l|}{ Personal Traits } \\
\hline - $\quad$ EXTRA: Extraversion & 2 & .785 \\
\hline - $\quad$ CON: Conscientiousness & 3 & .604 \\
\hline EMOSTA: Emotional Stability & 3 & .725 \\
\hline - $\quad$ OPEN: Openness to New Experiences & 4 & .691 \\
\hline - $\quad$ AGREE: Agreeableness & 4 & .757 \\
\hline SONO: Social Norms & 5 & .655 \\
\hline $\begin{array}{l}\text { KMO index of Dependent variables }=.811 \text {, and } \mathrm{Si} \\
\text { Total Variance Explained }=50.3 \% . \\
\text { KMO index of independent variables }=.790 \text {, and } \mathrm{S} \\
\text { Total Variance Explained }=58.1 \% . \\
\text { All items have factor loading } \geq 0.5\end{array}$ & & \\
\hline
\end{tabular}

Table 2 presents demographic characteristics of the present sample. It illustrates that among 2,141 participants, there are 1016 respondents accounted for $47.5 \%$ were male, and there were 1,125 respondents accounted for $52.5 \%$ were female. Next, the age group ranged between 20 and 25 accounted for $89.2 \%$, and the age group ranged between 26 and 30 accounted for $10.8 \%$. Marital status of the participants reported that are single accounted for $97.2 \%$, and they are married accounted for $2.8 \%$. Currently the highest field of study was business area accounted for $44.3 \%$. The second field of study was Natural Science area accounted for $33.2 \%$. Moreover, Social Science area accounted for $22.5 \%$. Besides that, the highest educational grade was third year student accounted for $48.1 \%$, then last year student accounted for $38.8 \%$ and graduated less than 1 year accounted for $13.2 \%$. Finally, list of the name of university are shown in Table 2.

Table 2

Demographic characteristics of participants $(\mathrm{N}=2141)$

\begin{tabular}{|c|c|c|c|}
\hline & & Number & $\%$ \\
\hline \multirow{2}{*}{ Gender } & Male & 1016 & 47.5 \\
\hline & Female & 1125 & 52.5 \\
\hline \multirow{2}{*}{ Age Group } & $20-25$ & 1909 & 89.2 \\
\hline & $26-30$ & 232 & 10.8 \\
\hline \multirow{13}{*}{ University } & Hong Bang International University & 195 & 9.1 \\
\hline & Hoa Sen University & 184 & 8.6 \\
\hline & Nguyen Tat Thanh University & 188 & 8.8 \\
\hline & Van Hien University & 175 & 8.2 \\
\hline & University of Finance-Marketing & 178 & 8.3 \\
\hline & Hutech University & 243 & 11.3 \\
\hline & Ho Chi Minh City University of Technology - Vietnam National University HCM City & 175 & 8.2 \\
\hline & International University - Vietnam National University HCM City & 196 & 9.2 \\
\hline & University of Social Sciences and Humanities - Vietnam National University HCM City & 131 & 6.1 \\
\hline & University of Science - Vietnam National University HCM City & 184 & 8.6 \\
\hline & University of Information Technology - Vietnam National University HCM City. & 116 & 5.4 \\
\hline & University of Economic and Law - Vietnam National University HCM City & 176 & 8.2 \\
\hline & Business Area & 949 & 44.3 \\
\hline \multirow[t]{2}{*}{ Field of Study } & Natural Science Area & 711 & 33.2 \\
\hline & Social Science Area & 481 & 22.5 \\
\hline \multirow{2}{*}{ Marital Status } & Single & 2080 & 97.2 \\
\hline & Married & 61 & 2.8 \\
\hline \multirow{3}{*}{$\begin{array}{l}\text { Educational } \\
\text { Grade }\end{array}$} & Third year student & 1029 & 48.1 \\
\hline & Last year student & 830 & 38.8 \\
\hline & Graduated less than 1 year & 282 & 13.2 \\
\hline
\end{tabular}

The results, as shown in Table 3 display the standard deviation, the means, the correlation coefficients between all study variables and entrepreneurial intention (ENIN). All current study variables had positive correlations with ENIN. Personal traits of openness to new experiences (OPEN: $r=.102)$; emotional stability (EMOSTA $: r=.084)$, extraversion (EXTRA: $r$ $=.098)$; conscientiousness $(\mathrm{CON}: \mathrm{r}=.046)$; social norms ( $\mathrm{SONO}: \mathrm{r}=.182)$, and positive attitudes $(\mathrm{POSAT}: \mathrm{r}=.254)$. These variables were retained, the better personal traits of openness to new experiences, emotional stability, extraversion, conscientiousness; social norms; and positive attitudes are, the higher student's entrepreneurial intention is. Specially, the largest correlation is between positive attitudes and entrepreneurial intention or the better positive attitudes increase, the higher student' entrepreneurial intention is. However, only AGREE and NEGAT had negative correlation with ENIN in small scale (AGREE, " $\mathrm{r}=-.126 ")$ and (NEGAT, " $\mathrm{r}=-.046 ")$. It means that the lowest level of negative attitudes and agreeableness are, the highest level of the entrepreneurial intention is. 
Table 3

Pearson's Correlation Coefficients between Variables and ENIN

\begin{tabular}{|c|c|c|c|c|c|c|c|c|c|}
\hline & ENIN & 1 & 2 & 3 & 4 & 5 & 6 & 7 & 8 \\
\hline 1. AGREE & -.126 & 1.000 & & & & & & & \\
\hline 2. OPEN & .102 & -.045 & 1.000 & & & & & & \\
\hline 3. SONO & .182 & -.055 & .129 & 1.000 & & & & & \\
\hline 4. EMOSTA & .084 & -.424 & .107 & .134 & 1.000 & & & & \\
\hline 5. $\mathrm{CON}$ & .046 & -.081 & .412 & .143 & .051 & 1.000 & & & \\
\hline 6. EXTRA & .098 & .245 & .352 & .207 & -.034 & .261 & 1.000 & & \\
\hline 7. POSAT & .254 & .014 & .264 & .382 & .044 & .256 & .321 & 1.000 & \\
\hline 8. NEGAT & -.046 & .022 & .221 & .239 & .049 & .225 & .257 & .407 & 1.000 \\
\hline Mean & 2.76 & 3.21 & 3.70 & 3.51 & 3.22 & 3.68 & 3.94 & 3.70 & 3.94 \\
\hline Std. Deviation & .814 & .876 & .673 & .616 & .863 & .731 & .799 & .614 & .618 \\
\hline
\end{tabular}

\subsection{Hypotheses testing}

Table 4 displays that four factors had significant and positive effects on POSAT (see model 1) with significance level of .000, we start with using POSAT as dependent variable. Based on ANOVA: F $(6,2134)=111.289$, Sig. $=.000, p<0.05$, the correctly predicted the positive attitudes at confidence level of $95 \%$ stating that it was representative for this regression equation and measured significant in this examination. Furthermore, the significance of the effect on $\mathrm{R}^{2}=.238$ shows that $23,8 \%$ of positive attitudes can be estimated by six independent variables, even though the remark of $76.2 \%$ of the change in positive attitudes could be defined by other elements. Therefore, the coefficients of determination were far to reach 1 (adjusted $\mathrm{R}^{2}=$ 0.238). After analyzing regression, there were two factors which did not have significant level of affection from AGREE with the Sig. value of $.812(P>.05)$, EMOSTA with the Sig. value of $.589(P>.05)$ and factors fail to affect positive attitudes, the results did not confirm the positively affected and predicted POSAT staying that the developing in those factors did not produce the increasing in positive attitudes. There were only four factors to have positive direct effects on POSAT with Sig. value $P<.05$. The findings confirmed the hypothesis 1 and the results also indicated that OPEN with $\beta=.100$ at Sig. value of $.000(p<.05)$, CON with $\beta=.098$ at Sig. value of $.000(p<.05)$, EXTRA with $\beta=.144$ at Sig. value of $.000(p<.05)$, SONO with $\beta=.312$ at Sig. value of $.000(p<.05)$ positively affected student' entrepreneurial intention. It showed that the increasing in these four factors would lead to the increasing in POSAT. The hypothesis 1 was supported at confidence level of $95 \%$ and the formulated as below:

Model 1

$\mathrm{Ys}=\beta 0+\beta 1 \mathrm{X} 1+\beta 2 \mathrm{X} 2+\beta 3 \mathrm{X} 3+\beta 4 \mathrm{X} 4$

$\mathrm{POSAT}=1.344+.100 \mathrm{OPEN}+.098 \mathrm{CON}+.144 \mathrm{EXTRA}+.312 \mathrm{SONO}$

Table 4

Coefficients between POSAT and independent variables

\begin{tabular}{|c|c|c|c|}
\hline Construct & Unstandardized Coefficients $(\beta)$ & t-value & Significance level \\
\hline (Constant) & 1.344 & 11.256 & .000 \\
\hline AGREE & -.004 & -.238 & .812 \\
\hline OPEN & .100 & 5.046 & .000 \\
\hline SONO & .312 & 15.979 & .000 \\
\hline EMOSTA & -.008 & -.504 & .589 \\
\hline CON & .098 & 5.536 & .000 \\
\hline EXTRA & .144 & 8.666 & .000 \\
\hline
\end{tabular}

Table 5 presents the findings of model 2, we start with using NEGAT as dependent variable. Based on ANOVA: F (6, 2134) $=53.464$, Sig. $=.000, p<0.05$, the regression equation was reflected on correctly forecasting the effect of negative attitudes. In addition, the significance of alter $\mathrm{R}^{2}=.131$ shows that $13,1 \%$ of negative attitudes can be estimated by six independent variables as illustrated above, even though the remark of $86.9 \%$ of the change in negative attitudes could be defined by other elements. Thus, the coefficient of determination is far to reach 1 "adjusted $\mathrm{R}^{2}=0.131$ ", the best change in the negative attitudes was depicted by the regression in model 2. After analyzing regression, there were two factors not significant level of affection from EMOSTA with Sig. value of .319 (P >.05), AGREE with Sig. value of .429 (P >.05) these factors fail to affect positive attitudes, the results did not confirm positively affecting attitudes. There were only four factors which had positively direct effects on NEGAT with Sig. value $\mathrm{P}<.05$ which have strong, positive impacts on negative attitudes from OPEN with $\beta=$ .085 at Sig. value of $.000(\mathrm{p}<.05), \mathrm{CON}$ with $\beta=.104$ at Sig. value of $.000(\mathrm{p}<.05)$, EXTRA with $\beta=.117$ at Sig. value of $.000(\mathrm{p}<.05)$, SONO with $\beta=.177$ at Sig. value of $.000(\mathrm{p}<.05)$. The findings confirmed the hypothesis 2 , which means that 1 -standard deviation increase in these factors is associated with an increase in the score of negative attitudes values. In this case, every 1 -standard variance added on these factors lead to an increase score of .085; .104; .117; .177 in NEGAT as long as other elements were maintained in the act of "constants". It showed that increase in personal traits of openness to new 
experiences, extraversion, and conscientiousness; social norms lead to an increase in negative attitudes. The hypothesis 2 was supported at confidence level of $95 \%$ and the formulated as below:

Model 2

$\mathrm{Ys}=\beta 0+\beta 1 \mathrm{X} 1+\beta 2 \mathrm{X} 2+\beta 3 \mathrm{X} 3+\beta 4 \mathrm{X} 4$

$\mathrm{NEGAT}=2.068+.085 \mathrm{OPEN}+.104 \mathrm{CON}+.117 \mathrm{EXTRA}+.177 \mathrm{SONO}$

Table 5

Coefficients between NEGAT and independent variables

\begin{tabular}{lccc}
\hline Model & Unstandardized Coefficients $(\beta)$ & t-value & Significance level \\
\hline (Constant) & 2.068 & 16.117 & .000 \\
AGREE & .013 & .791 & .429 \\
OPEN & $\mathbf{. 0 8 5}$ & 3.977 & $\mathbf{. 0 0 0}$ \\
SONO & $\mathbf{1 7 7}$ & 8.424 & .997 \\
EMOSTA & .016 & 5.426 & .319 \\
CON & $\mathbf{. 1 0 4}$ & 6.549 & $\mathbf{. 0 0 0}$ \\
EXTRA & $\mathbf{. 1 1 7}$ & $\mathbf{0 0 0}$ \\
\hline
\end{tabular}

Model 2, using NEGAT: Negative Attitudes as Dependent Variable

ANOVA: $F(6,2134)=53.464$, Sig. $=.000, p<0.05$

Model summary: $\mathrm{R}^{2}=.131$

Table 6 presents the findings of model 3, we start with using ENIN as dependent variable. Based on ANOVA: F (8, 2132) = 37.767 , Sig. $=.000, p<0.05$. The regression equation was reflected on correctly predicting the attitude of entrepreneurial intention was measured significantly at confidence level of $95 \%$. Furthermore, the significance of the effect on $\mathrm{R}^{2}=.124$ shows that $4 \%$ of entrepreneurial intention can be estimated by eight independent variables as illustrated above, even though the remark of $87.6 \%$ of the change in students' entrepreneurial intention could be defined by other elements. So, the coefficient of determination is distant to reach 1 "adjusted $\mathrm{R}^{2}=0.124$ ", the best change in students' entrepreneurial intention was depicted by the regression in model 3. After analyzing regression, there were two factors not significant (i.e. EMOSTA with Sig. value of $.620(\mathrm{P}>.05), \mathrm{CON}$ with Sig. value of $.064(\mathrm{P}>.05))$. These factors fail to affect positive attitudes, the results did not confirm positively the prediction and the effect on ENIN. There were only six factors with Sig. value $(P<.05)$ acquired a strong, positive effect on students' entrepreneurial intention. The findings maintained the hypothesis 3 , which showed positive relationship between entrepreneurial intention and predictors of AGREE, OPEN, EXTRA, SONO, POSAT, and NEGAT on ENIN. This meant that one-standard variance added on OPEN with $\beta=.057$ at Sig. value of $.047(p<.05)$, EXTRA with $\beta=$ .068 at Sig. value of $.005(p<.05)$, SONO with $\beta=.136$ at Sig. value of $.000(p<.05)$, POSAT with $\beta=.362$ at Sig. value of $.000(\mathrm{p}<.05)$ could lead to an added on score of.057; .068; .136; .362 in ENIN, other elements were maintained in the act of "constants". These results suggested that personal traits of openness to new experiences, extraversion; social norms and positive attitudes had positive effects on ENIN that lead to an increase in ENIN. While AGREE; NEGAT devoted negative scores to ENIN. In this case, every one-standard deviation increases in NEGAT with $\beta=-.260$ at Sig. value of .000 ( $p<.05)$, AGREE with $\beta=-.123$ at Sig. value of $.000(p<.05)$, would lead to a decrease of score of .260 and .123 in ENIN. The hypothesis 3 was supported at confidence level of $95 \%$ and the formulated as below:

Model 3

$\mathrm{Ys}=\beta 0+\beta 1 \mathrm{X} 1+\beta 2 \mathrm{X} 2+\beta 3 \mathrm{X} 3+\beta 4 \mathrm{X} 4+\beta 5 \mathrm{X} 5+\beta 6 \mathrm{X} 6$

$\mathrm{ENIN}=2.025+.057 \mathrm{OPEN}+.068 \mathrm{EXTRA}+.362 \mathrm{POSAT}+.136 \mathrm{SONO}-.260 \mathrm{NEGAT}-.123 \mathrm{AGREE}$

Table 6

Coefficients between ENIN and independent variables

\begin{tabular}{|c|c|c|c|}
\hline Model & Unstandardized Coefficients $(\beta)$ & t-value & Significance level \\
\hline (Constant) & 2.025 & 11.149 & .000 \\
\hline AGREE & -.123 & -5.651 & .000 \\
\hline OPEN & .057 & 1.989 & .047 \\
\hline SONO & .136 & 4.593 & .000 \\
\hline EMOSTA & .011 & .496 & .620 \\
\hline $\mathrm{CON}$ & -.047 & -1.856 & .064 \\
\hline EXTRA & .068 & 2.806 & .005 \\
\hline POSAT & .362 & 11.277 & .000 \\
\hline NEGAT & -.260 & -8.688 & .000 \\
\hline
\end{tabular}

Model 3, using ENIN: Entrepreneurial Intention as Dependent Variable

ANOVA: $F(8,2132)=37.767$, Sig. $=.000, p<0.05$

Model Summary: $R^{2}=.124$ 


\subsection{Indirect impact on students' entrepreneurial intention}

Preacher and Hayes (2008) stated that the indirect impact on an independent variable on the dependent variable through a mediating variable was the total product of the effects of that independent variable on the mediating variable and the effect of the mediating variable on the dependent variable (Preacher \& Hayes, 2008). Table 4 shows the results of a multiple regression analysis where POSAT was significantly affected by four independent variables (OPEN, CON, EXTRA, and SONO), the results from Table 5 show NEGAT was significantly affected by four independent variables too (OPEN, CON, EXTRA, and SONO). Moreover, the results found that POSAT and NEGAT had direct effects on students' entrepreneurial intention $(\beta=$ $.362, p<.01 ; \beta=-.260, p<.01)$. Hence, through the mediating variables, there were four independent variables which had indirect effects on students' entrepreneurial intention: OPEN at $(\beta=.0142)$; SONO at $(\beta=.067)$; CON at $(\beta=.329)$ and EXTRA at $(\beta=.0217)$, the hypothesis 4 was supported, as shown in Table 7.

Table 7

Summary of direct, indirect, and total causal effects

\begin{tabular}{|c|c|c|c|c|c|c|c|}
\hline & \multicolumn{3}{|c|}{ Casual Effects } & \multicolumn{2}{|c|}{ POSAT } & \multicolumn{2}{|c|}{ NEGAT } \\
\hline & Direct & Indirect & Total & $\mathbf{L L}$ & UP & $\mathbf{L L}$ & UP \\
\hline AGREE & -.123 & -------- & -.123 & -.0106 & .0076 & -.0107 & .0036 \\
\hline OPEN & .057 & .014 & .071 & .0236 & .0496 & -.0326 & -.0124 \\
\hline SONO & .136 & .067 & .203 & .0934 & .1336 & -.0594 & -.0339 \\
\hline EMOSTA & --------- & --------- & ------- & ------ & ------ & ------- & ------- \\
\hline $\mathrm{CON}$ & ---------- & .329 & .329 & .0239 & .0481 & -.037 & -.0176 \\
\hline EXTRA & .068 & .0217 & .089 & .0398 & .0651 & -.0406 & -.0213 \\
\hline POSAT & .362 & --------- & .362 & ----- & ----- & ------- & ----- \\
\hline NEGAT & -.260 & ----------- & -.260 & ----- & ------ & ----- & ----- \\
\hline Total & 0.24 & 0.4317 & 0.671 & & & & \\
\hline
\end{tabular}

\subsection{Significance of the indirect effects}

Table 7 shows an overview of direct, indirect and total casual effects on entrepreneurial intention. We used the method of bootstrapping, recommended by the Preacher and Hayes (2008) to analysis the significance of indirect effect on ENIN through mediation variables with confidence interval at $90 \%$, which was provided by the outputs. In the case, it got a "ZERO" - 0 lies in the interval range between "the upper boundary (UL) and the lower boundary (LL)", then we can conclude that, with $90 \%$ - confidence interval, it did not have the significance of indirect effect through mediation variables. Differently, the zero did not appear between the UL and the LL, so we can wrap up that, with $90 \%$ - confidence interval, it had the significance of indirect effect through mediation variables (Preacher \& Hayes, 2004). The outputs, as shown in Table 7, agree with the predictions by the Preacher and Hayes (2004). Since the zero was not in the $90 \%$ - confidence interval, we can conclude that the indirect effects of OPEN, CON, EXTRA, and SONO were meaningful with $p<.05$ (two tailed) and the mediation of POSAT and NEGAT in this research were absolutely correct. Therefore, the hypothesis 4 was supported.

\subsection{The causal effects of students' entrepreneurial intention}

Based on the findings, the POSAT factor got the strongest significant and positive effect on students' entrepreneurial intention, with $\beta=.362$, followed by CON with $\beta=.329$; SONO with $\beta=.203$; EXTRA with $\beta=.089$; OPEN with $\beta=.071$; but NEGAT and AGREE factors got a significant and negative effect on ENIN (NEGAT with $\beta=-.260$; and AGREE with $\beta=-.123$ ). Lastly, the total positive effect of these factors on students' entrepreneurial intention got 0.671 (See Fig. 1).

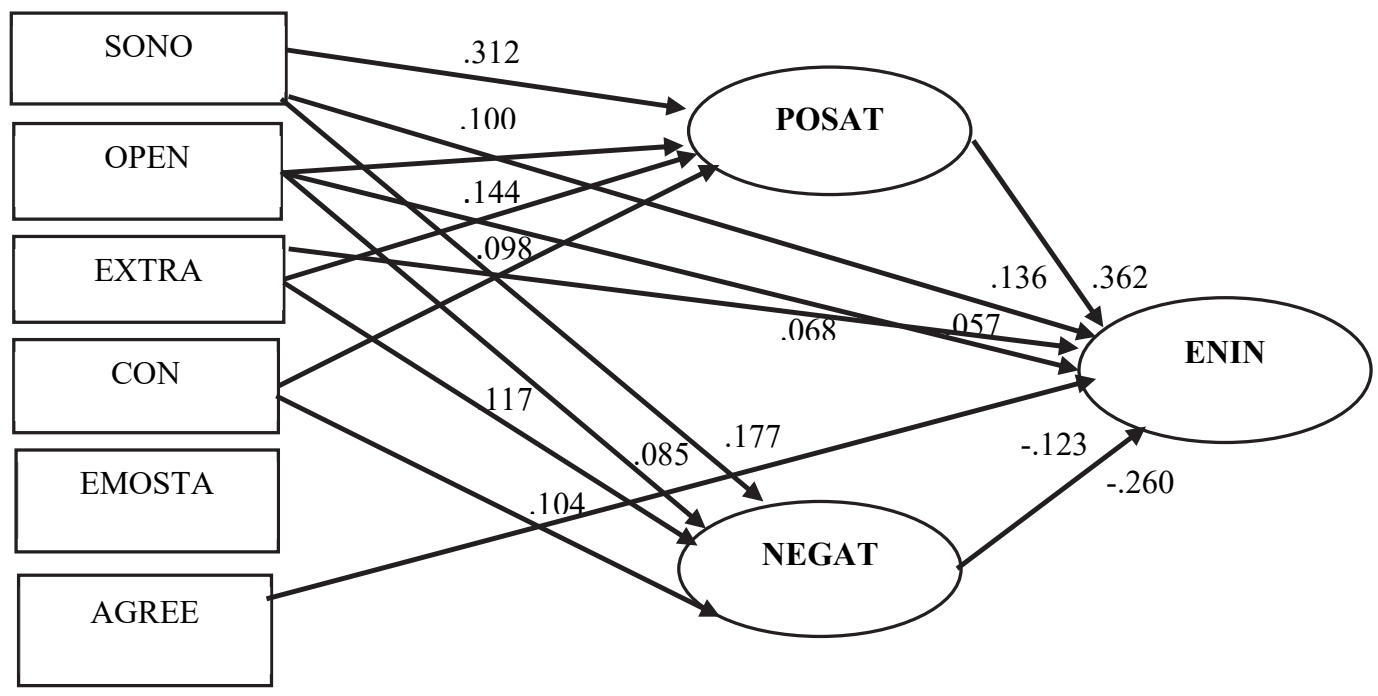

Fig. 1. Path coefficients of hypothesis testing 


\section{Discussions}

In this section, we discuss and answer the questions raised in hypotheses with the objective of improving the deepest understanding about the relationship between six independent factors (personal traits of extraversion, conscientiousness, emotional stability, openness to new experiences, agreeableness; and social norms), two mediation variables (positive and negative attitudes) and the dependent variable (entrepreneurial intention).

According to the descriptive analysis, the largest number of the students were in the field of study for the business area (about $44.3 \%$ ), and the educational grade was for third year student accounted for $48.1 \%$ with 1,029 students' respondents, accounting for the biggest percentage of those studying at twelve universities in Ho Chi Minh City. This showed that business field is a future area for growing students' entrepreneurial intention, implications for reforming educational program should invest more subjects related in startups in the business field to make students achieve strong knowledge to jump on a new business, such as establishing a model company for students to run a small business and monitoring the development of this new business by themselves.

Our results have illustrated the direct and indirect effects of the personal traits and social norms on students' entrepreneurial intention. This research can draw a conclusion that the mediate variables of attitude towards the entrepreneurship includes positive attitudes, which got the strongest effect on students' entrepreneurial intention. The results are consistent with "TBP model" by Heuer and Liñán (2013) and found a significant indirect effect of social norms via attitudes towards SE-intention $(\beta=.27, p<.01)$. It played the most important role in entrepreneurial intention and the negative attitudes had significant and negative effect directly on students' entrepreneurial intention. This finding was similar to Douglas \& Shepherd (2002) who found both POSAT and NAGAT had "direct and indirect effects are both utilities and increase the probability of self-employment". Their research assessed "Employment or self-employment a dynamic utility-maximizing model". It was emphasized that "Different individuals experience different changes over time in their ability as well as in their attitudes toward income, work effort, risk, and independence, and these may alter a career path", and "Attitudes can be learned; therefore, those entities trying to encourage people to be self-employed would be well-advised to understand not only how utility weights change over time but also how education and other environmental factors can mold attitudes". These results demonstrated that the attitude towards the entrepreneurship of students from twelve universities in Ho Chi Minh City had a higher entrepreneurial intention. When students had a higher perceived value of attitude towards the entrepreneurship, they could not feel starting own business is risky. On the basis of relevant literature review, similar to the result, Douglas \& Shepherd (2002); and Shapero \& Sokol (1982) indicated that the attitude towards the entrepreneurship were associated with entrepreneurial intention, their findings showed that "lower risk is associated with higher utility and higher independence and higher income are associated with higher utility, indicating that people prefer both independence and income".

The results of path analysis showed the direct and indirect effects on students' entrepreneurial intention. The findings indicated that personal traits of openness to new experiences and extraversion had direct and indirect effects on students' entrepreneurial intention, these findings are matched by some previous researchers (Antoncic et al., 2005; Kovaleva, 2013; Krueger, 2000), while there was only conscientiousness which had indirect effect on students' entrepreneurial intention, whereas emotional stability did not have impact on students' entrepreneurial intention. Nga \& Shamuganathan (2010) and Caballero et al. (2013) also proposed that the agreeableness, openness and conscientiousness can be applied to predict the social entrepreneurial intention. Moreover, Zhao and Seibert (2006) also placed an emphasis on the openness and agreeableness elements associated with the willingness to become an entrepreneur (Caballero, et al. 2013). Zhao et al. (2010) showed that the four majors Big Five elements direct influences the entrepreneurial intentions (all but except the agreeableness). However, in this study, the findings of agreeableness had direct influences on students' entrepreneurial intention.

Furthermore, social norms had direct and indirect effects on students' entrepreneurial intention, these findings are matched by some previous researchers (Ajzen 1988; Shapero \& Sokol, 1982; and Nguyen \& Phan, 2014). Ajzen (1988) interpreted the term "social norm" like the individual's discretion of communal tension to operate or not to operate the attitudes under inspection. In other words, it displays a person's perspective of values, mindset, assumptions, and observances which are occupied by the others who affect significantly to him/her or whom he/she really appreciates. For instance, due to the beliefs of the majority in the society, parents in Vietnam have the tendency to place the pressure and force their children to become "doctor" or "engineer" as the future career because those occupations are acknowledged as the reputable and far-famed business. According to Krueger (2000) "Friends' comments affect my entrepreneurship intention; my parents' advice affect my entrepreneurship intention; famous and successful businessmen affect my decision to become an entrepreneur/I have a lot of respect for successful businessmen". According to World Economic Forum (2013) "Business information on the mass media effects my entrepreneurship intention". These results were supported the arguments made by Nguyen and Phan (2014) who demonstrated the impacts of personal traits and motives for the youthful people in Vietnam, especially the senior students "realize the importance of social status and expect to have a high social status" (Social status - motive factor - Nguyen \& Phan, 2014). Furthermore, Shapero and Sokol's (1982) showed that "the proposed framework rests on the recognition that entrepreneurial activities are results of social interactions and mechanisms". According to Krueger (2000) "the theory of planned behavior" the effects of social norms on intention, but the social norms factor was not significant. 


\section{Conclusion and implications}

This study has answered the research's objectives to determine the elements influencing on students' entrepreneurial intention and tested the direct and indirect effects of these factors. We have analyzed the data that were collected from 2,141 respondents who were studying at twelve universities in Ho Chi Minh City from November 2019 to August 2020. The study discovered there were seven factors affecting directly and indirectly on students' entrepreneurial intention; including personal trait of extraversion, conscientiousness, openness to new experiences, agreeableness and social norms and had positive and negative attitudes, except the factor of emotional stability which did not show either direct or indirect effect on students' entrepreneurial intention. Based on the demographic characteristics of sample, there were 1,029 respondents who were the third-year student accounted for $48.1 \%$ which indicated that students wished to "create jobs" before graduation, the new business ventures were created in students' mindsets every day. These results generated practical implications' entrepreneurship education should create a new curriculum through education and learning in the real-life experiences such as creating a mini company in class or a model company in university for learning purposes. In Vietnam, there are only few universities having business administration to support entrepreneurship program, however the curriculum is still short of realistic and applicable, which confined students' ability to rise up a new business.

First, the universities should create some courses for students to understand more on how to do a new business, what skills they need, why they need to have startups or run a business, and finally after finishing these courses they will get a certificate in business startup program. We should have a specific education system such as the startups program courses that offers students the opportunity to learn the process parallel with starting a new enterprise through a series of collaboration with companies to let students practice there and do authentic learning experiences from the real world. Specifically, students will learn about the process of planning, launching and building a venture, students will gain through the real-life experience of doing business plans by themselves, as well as engaging with companies' staffs, executives, industry professional experts and local startups.

Second, the universities should add some subjects like "critical thinking and problem solving" since every new venture begins with an idea. Moreover, the universities should have some rewards for students who have startups a new business to encourage and bring a high motivation for success. Last year Mr. Thanh said the project 1665 was approved by Prime Minister Nguyen Xuan Phuc who supported student entrepreneurship from 2017 to 2020 "with a vision towards 2025" and purposed "equipping college students with the basic knowledge and skills on how to start a business, and more importantly, changing the mindsets of students regarding entrepreneurship" (Vietnamnews, 2018). According to Vietnamnews (2018), The project 1665 only concentrates on "supporting students to learn and develop their entrepreneurship spirit and called on relevant stakeholders including schools and businesses for nurturing the spirit". Thus, this is a big opportunity for all universities to encourage students establishing startups.

Despite the fact that this research has reached its goals, it still got some limitations. First limitation is associated with the nonprobabilistic sample that we used to collect data in twelve universities in two-way face to face and online survey during corona virus disease (Covid-19) break out. Thus, we could not reach well our goals of sample size. The second limitation is that the students did not have any awareness about the importance of answering the survey, they were not willing to help us answer the survey for example there was a university where we sent surveys directly to over 1,600 students' email, but we did not get any surveys back. In this case if we could have met students at their class, then we would have explained more details on why they should help us answer these surveys and because of corona virus disease we got a distant gap with students. All students stayed at home to study online, so they were not at the class. Then we have to contact with other universities to ask their permission to come to collect data in May 2020. Third limitation was the data collection was conducted at only a short time from November 2019 to August 2020 during this time students were not at universities, and they were at different places in Vietnam to answer online surveys, if this research could have collected data in different years without corona virus disease, the findings would have increased the generalizability. Finally, the research used existing variables to test the effects on students' entrepreneurial intention in context of Vietnam. In the future research we could improve more potential elements that could be significant elements of students' entrepreneurial intention and use qualitative approach to conduct an in-depth interview among students about startups.

\section{Funding}

This work is funded by Hong Bang International University under grant code GV2004.

\section{References}

Ajzen, I. (1988). Attitudes, traits, and actions: Dispositional prediction of behavior in personality and social psychology. In Advances in experimental social psychology (Vol. 20, pp. 1-63). Academic Press.

Ajzen, I. (1991). The theory of planned behavior. Organizational Behavior and Human Decision Processes, 50(2), $179-211$.

Ajzen, I., \& Fishbein, M. (2005). The influence of attitudes on behavior. In Albarracín, D., Johnson, B.T. and Zanna, M.P. (Eds), The Handbook of Attitudes, Erlbaum, Mahwah, NJ, pp. 173-221.

Antoncic, B., Bratkovic Kregar, T., Singh, G., \& DeNoble, A. F. (2015). The big five personality-entrepreneurship relationship: Evidence from Slovenia. Journal of Small Business Management, 53(3), 819-841. 
Ashton, M. C., Lee, K., \& Paunonen, S. V. (2002). What is the central feature of extraversion? Social attention versus reward sensitivity. Journal of Personality and Social Psychology, 83(1), 245.

Brockhaus Sr, R. H. (1980). Risk taking propensity of entrepreneurs. Academy of management Journal, 23(3), 509-520.

Caballero, S., Fuchs, R. M., \& Prialé, M. A. (2013). The influence of personality traitson social enterprise start up: the case of Peruvian social entrepreneurs. In IV EMES International Research Conference on Social Enterprise Liege (Vol. 4, pp. 1-18).

Carland, J. W., Hoy, F., Boulton, W. R., \& Carland, J. A. C. (1984). Differentiating entrepreneurs from small business owners: A conceptualization. Academy of Management Review, 9(2), 354-359.

Churchill, N., \& Bygrave, W. D. (1989). The Entrepreneur ship Paradigm (I): A Philosophical Look at Its Research Methodologies. Entrepreneurship Theory and Practice, 14(1), 7-26.

Ciavarella, M. A., Buchholtz, A. K., Riordan, C. M., Gatewood, R. D., \& Stokes, G. S. (2004). The Big Five and venture survival: Is there a linkage?. Journal of Business Venturing, 19(4), 465-483.

Ćcćkalo, E. T. M. N. D., \& Rajković, S. B. J. (2018) The Impact of the Big Five Personality Traits on Enterprise Potential and Individual Entrepreneurial Orientation of Students in Serbia. INNOVATION MANAGEMENT, ENTREPRENEURSHIP AND SUSTAINABILITY, 1047.

De Clercq, D., Honig, B., \& Martin, B. (2013). The roles of learning orientation and passion for work in the formation of entrepreneurial intention. International Small Business Journal, 31(6), 652-676.

Douglas, E. J., \& Shepherd, D. A. (2000). Entrepreneurship as a utility maximizing response. Journal of Business Venturing, $15(3), 231-251$.

Douglas, E. J., \& Shepherd, D. A. (2002). Self-employment as a career choice: Attitudes, entrepreneurial intentions, and utility maximization. Entrepreneurship theory and practice, 26(3), 81-90.

Duchesneau, D. A., \& Gartner, W. B. (1990). A profile of new venture success and failure in an emerging industry. Journal of Business Venturing, 5(5), 297-312.

Eisenhauer, J. G. (1995). The entrepreneurial decision: Economic theory and empirical evidence. Entrepreneurship Theory and Practice, 19(4), 67-79.

Elfving, J., Brännback, M., \& Carsrud, A. (2009). Toward a contextual model of entrepreneurial intentions. In Understanding the entrepreneurial mind (pp. 23-33). Springer, New York, NY.

Fitzsimmons, J. R., \& Douglas, E. J. (2011). Interaction between feasibility and desirability in the formation of entrepreneurial intentions. Journal of Business Venturing, 26(4), 431-440.

Goldberg, L. R. (1981). Language and individual differences: The search for universals in personality lexicons. Review of Personality and Social Psychology, 2(1), 141-165.

Graziano, W. G., \& Eisenberg, N. (1997). Agreeableness: a dimension of personality. R. Hogan, J. Johnson, S. Briggs, 794825 .

Gregoire, D.A., Noel, M.X., Dery, R., \& Bechard, J.P. (2006). Is there conceptual convergence in entrepreneurship research? A co-citation analysis of the frontiers of entrepreneurship research, 1981-2004. Entrepreneurship Theory and Practice, 30(3), 333-73.

Hair, J. F. (1995). Multivariate Data Analysis with Readings. Englewood Cliffs.

Hair, J. F., Anderson, R. E., Tatham, R. L., \& Black, W. C. (1987). Multivariate data analysis with readings. Tulsa, OK: Petroleum Publishing.

Heuer, A., \& Liñán, F. (2013). Testing alternative measures of subjective norms in entrepreneurial intention models. International Journal of Entrepreneurship and Small Business, 19(1), 35-50.

Hinkle, D. E., Wiersma, W., \& Jurs, S. G. (1998). Applied statistics for the behavioral sciences (Vol. 663). Houghton Mifflin College Division.

Hogan, J., \& Ones, D. S. (1997). Conscientiousness and integrity at work. In Handbook of personality psychology (pp. 849870). Academic Press.

Kerlinger, F. N., \& Lee, H. B. (1986). Foundations of behavioral research, Fort Worth. TX: Holt, Rinehart, Winston.

Knight, F. H. (1921). Risk, uncertainty and profit (Vol. 31). Houghton Mifflin.

Nga, J. K. H., \& Shamuganathan, G. (2010). The influence of personality traits and demographic factors on social entrepreneurship start up intentions. Journal of Business Ethics, 95(2), 259-282.

Korber, S., \& McNaughton, R. B. (2018). Resilience and entrepreneurship: a systematic literature review. International Journal of Entrepreneurial Behavior \& Research.

Kovaleva, A., Beierlein, C., Kemper, C. J., \& Rammstedt, B. (2013). Psychometric properties of the BFI-K: A cross-validation study. The International Journal of Educational and Psychological Assessment.

Krueger Jr, N. F. (2007). What lies beneath? The experiential essence of entrepreneurial thinking. Entrepreneurship Theory and Practice, 31(1), 123-138.

Krueger Jr, N. F., Reilly, M. D., \& Carsrud, A. L. (2000). Competing models of entrepreneurial intentions. Journal of Business venturing, 15(5-6), 411-432.

Krueger, N. F. (2017). Entrepreneurial intentions are dead: Long live entrepreneurial intentions. In Revisiting the entrepreneurial mind (pp. 13-34). Springer, Cham.

Krueger, N. F., \& Carsrud, A. L. (1993). Entrepreneurial intentions: Applying the theory of planned behaviour. Entrepreneurship \& Regional Development, 5(4), 315-330. 
Lucas, R. E., Diener, E., Grob, A., Suh, E. M., \& Shao, L. (2000). Cross-cultural evidence for the fundamental features of extraversion. Journal of Personality and Social Psychology, 79(3), 452.

McCrae, R. R., \& Costa Jr, P. T. (1997). Conceptions and correlates of openness to experience. In Handbook of personality psychology (pp. 825-847). Academic Press.

McCrae, R. R., \& Costa, P. T. (1999). A five-factor theory of personality In Pervin LA \& John OP (Eds.), Handbook of personality: Theory and Research (pp. 139-153). New York: Guilford.

Nguyen, M., \& Phan, A. (2014). Entrepreneurial Traits and Motivations of the Youth-an Empirical Study in Ho Chi Minh City-Vietnam. International Journal of Business and Social Science, 5(5).

Obschonka, M., Silbereisen, R. K., \& Schmitt-Rodermund, E. (2010). Entrepreneurial intention as developmental outcome. Journal of Vocational Behavior, 77(1), 63-72.

Pallant, J. (2007). SPSS survival manual: A step by step guide to data analysis using IBM SPSS. Routledge.

Preacher, K. J., \& Hayes, A. F. (2004). SPSS and SAS procedures for estimating indirect effects in simple mediation models. Behavior Research Methods, Instruments, \& Computers, 36(4), 717-731.

Rees, H., \& Shah, A. (1986). An empirical analysis of self-employment in the UK. Journal of Applied Econometrics, 1(1), 95-108.

Remeikiene, R., Dumciuviene, D., \& Startiene, G. (2013). Explaining entrepreneurial intention of university students: The role of entrepreneurial education. In Active Citizenship by Knowledge Management \& Innovation: Proceedings of the Management, Knowledge and Learning International Conference 2013 (pp. 299-307). ToKnowPress.

Robbins, S. P., \& Judge, T. A. (2007). Organizational behavior (12th ed.). Upper Saddle River, NJ: Pearson Prentice Hall.

Schumpeter, J.A. (1934). The Theory of Economic Development: An Inquiry into Profits, Capital, Credit, Interest, and the Business Cycle. Harvard University Press, Cambridge, MA.

Shapero, A., \& Sokol, L. (1982). The social dimensions of entrepreneurship. Encyclopedia of Entrepreneurship, 72-90.

Shepherd, D. A., Douglas, E. J., \& Fitzsimmons, J. R. (2008). MBA admission criteria and an entrepreneurial mind-set: Evidence from "western" style MBAs in India and Thailand. Academy of Management Learning \& Education, 7(2), 158172.

Turker, D., \& Selcuk, S. S. (2009). Which factors affect entrepreneurial intention of university students?. Journal of European industrial training.

Watson, D., \& Clark, L. A. (1997). Extraversion and its positive emotional core. In Handbook of personality psychology (pp. 767-793). Academic Press.

Widiger, T. A., \& Costa Jr, P. T. (1994). Personality and personality disorders. Journal of Abnormal Psychology, $103(1), 78$.

Wiggins, J. S., \& Trapnell, P. D. (1997). Personality structure: The return of the Big Five. In Handbook of personality psychology (pp. 737-765). Academic Press.

Zhao, H., \& Seibert, S. E. (2006). The big five personality dimensions and entrepreneurial status: A meta-analytical review. Journal of Applied Psychology, 91(2), 259.

Zhao, H., Seibert, S. E., \& Lumpkin, G. T. (2010). The relationship of personality to entrepreneurial intentions and performance: A meta-analytic review. Journal of Management, 36(2), 381-404.

Wikipedia (2020). List of universities in Ho Chi Minh City. Retrieved September 27, 2020 from https://en.wikipedia.org/wiki/List_of_universities_in_Ho_Chi_Minh_City.

Vietnamnews (2018). Viet Nam wants to nurture entrepreneurship among kids. Retrieved September 27, 2020 from https://vietnamnews.vn/society/482158/viet-nam-wants-to-nurture-entrepreneurship-among-kids.html

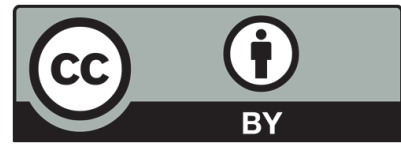

(C) 2021 by the authors; licensee Growing Science, Canada. This is an open access article distributed under the terms and conditions of the Creative Commons Attribution (CC-BY) license (http://creativecommons.org/licenses/by/4.0/). 